\title{
Status of Farm Mechanization under Animal Farming in Bastar Plateau Agro-climatic Zone of Chhattisgarh
}

\author{
Amit Namdeo*, V. M. Victor and Navneet Kumar Dhruwe
}

SVCAET\& RS, Indira Gandhi Krishi Vishwavidyalaya, Raipur, (C.G.), India

*Corresponding author

\begin{tabular}{l} 
Ke y w o r d s \\
Farm \\
Mechanization, \\
Draught Animal, \\
Farm Implements, \\
Bastar plateau \\
\hline Article Info \\
\hline $\begin{array}{l}\text { Accepted: } \\
\text { 05 April } 2020 \\
\text { Available Online: } \\
\text { 10 May } 2020\end{array}$ \\
\hline
\end{tabular}

\section{Introduction}

Farm mechanization refers to the utilization of mechanical aids, improved farm implements to enhance the agricultural production. It may not include only tractors, farm mechanization considering also animaldrawn and human powered implements. The effective mechanization contributes to increased production in two major ways: firstly the timeliness of operation and secondly the good quality of work. The power required for different agricultural operations like land preparation, sowing, and harvesting appears inadequate due to the usage of traditional implements instead of improved farm implements.

As a result, the operations are either partially done or sometimes completely neglected, resulting in low yield due to poor growth or untimely harvesting or both. 
Farm mechanization has been helpful to bring about a significant improvement in agricultural productivity. Thus, there is a strong need for mechanization of agricultural operations. The factors that justify the strengthening of farm mechanization in the country can be numerous.

The timeliness of operations has assumed greater significant in obtaining optimal yields from different crops, which has been possible by way of mechanization. The factors that justify the strengthening of farm mechanization in the country can be numerous. The timeliness of operations has assumed greater significant in obtaining optimal yields from different crops, which has been possible by way of mechanization (Singh, 2002).

\section{Materials and Methods}

Chhattisgarh state consists of three zones i.e. Chhattisgarh Plain, Bastar plateau, Northern hills zones. For this particular study, Bastar plateau zone was selected. For this particular study two districts were selected from zone i.e. Bastar and Kondagaon were selected. In Bastar plateau Bastar district has Bakavand and Baster block and Kondagaon district has Keshkal and Kondagaon were selected purposely for a case study and from Kondagaon district, Makadi, Anantpur and Kerwahi villages from Keshkal block. From Kondagaon block Masora, Palli, Badekanera villages. In Baster district, Bagmohalai, Bakel and Mathota and from Bakavand block Kolawali, Satosa and Chinndgaon.

Ten farmers from each of the selected village will be considered to collect the required information. In all, a total 120 farmers were selected for the present study. To collect information leading to fulfilling the objectives of this study each farmer was interviewed separately on the pre- tested Proforma.
Inquiry method was adopted for obtaining the information from selected farmers falling into different categories. The time (in hours) required for various farm operations mainly field preparation, sowing, weeding, harvesting, threshing, and transportation etc. through draught animal were recorded for each crop on the basis of the verbal interview of the farmers.

The secondary data related to Chhattisgarh state is collected from the Commissioner, Land Records, Directorate of Animal Husbandry, a Statistical handbook of Chhattisgarh. Adopting standard techniques suggested by the research workers the data thus collected was processed. First of all the data for animal power utilization was arranged separately for different categories of respondents for each village. To identify the location of survey sites in the selected district of the zone, villages were grouped block wise. The farmers were selected randomly. The frequency, percentage and mean were calculated for precise and meaning analysis and interpreting of the data collected. Data were analysed for the most part by using the tabular form as for its inherent quality in portraying the true picture of draught animal and farmer involvement in agriculture and allied activities in the state of Chhattisgarh.

\section{Results and Discussion}

\section{Status of draught animals in bastar plateau}

District wise draught animal population is presented in Table No. 1. It was found that draught animals used in the zone comprise of Bullocks and he-buffaloes. Out of total draught animal population in Bastar plateau, Bastar district has a major share of 30.64 per cent and a minimum share of Bijapur district is 11.2 per cent. It shows the general information about the draught animal population in Bastar plateau. 
Availability of draught animal power and farm implements in bastar plateau

In Bastar plateau agro-climatic zone the draught animal power available is shown in Table No. 2. It shows that Kondagaon district has maximum power availability as 0.28 $\mathrm{kW} / \mathrm{ha}$ and the minimum was found in Dantewada district as $0.15 \mathrm{~kW} / \mathrm{ha}$. The average draught animal power found in Bastar plateau was $0.208 \mathrm{~kW} / \mathrm{ha}$ and Table No. 3 shows the availability of farm implements and bullock cart in different districts of Bastar plateau. It shows that Kanker district of Bastar plateau has maximum numbers of the wooden plough as 92666 and Narayanpur district has a minimum as 18031. Bastar district has maximum numbers of the iron plough as 1685 and Narayanpur have a minimum as 21 , but in the case of a bullock carts, again Kanker district has maximum 12051 and Dantewada has minimum 57 number of a bullock carts.

\section{Average utilization of animal power in Chhattisgarh}

To collect information on the extent of animal power utilization in the state primary data was collected from the respondents by asking them questions on different farm operations carried out using animal power, approximate duration of utilization for each operation and implement owned by them. Table No. 4 shows the average utilization of animal power for different operations in the selected villages of Bastar plateau agro-climatic zone. Badekanera village had the highest utilization of $271 \mathrm{~h} / \mathrm{ha}$ and lowest utilization was in Baghmohala village $193 \mathrm{~h} / \mathrm{ha}$. The draught animals are used for ploughing, planking, threshing and carting operations mainly. Table 4 also reveals that the ploughing operation requires the highest number of hours among all the field operations followed by threshing and carting. Ploughing has a share ranging between $30-50 \%$ of total usage of draught animals for different operations.

\section{Month wise utilization of draught animal}

The average monthly utilization of draught animals in Bastar plateau has been shown in Table No. 5. The highest utilization of draught animals was in the month of June and July mainly due to ploughing and seed bed preparation. However, draught animals are also engaged in the months of November and December in carting of harvest materials, but these values are very low as compared to the other months in which the animals are used for farm operations.

Table.1 Draught animal population in Bastar plateau

\begin{tabular}{|c|l|c|c|c|c|}
\hline S.No & Zone & District & Bullock & He- buffalo & Total \\
\hline $\mathbf{1}$ & & Bastar & 118689 & 40343 & 159032 \\
\hline $\mathbf{2}$ & \multirow{2}{*}{$\begin{array}{c}\text { Bastar } \\
\text { plateau }\end{array}$} & Kondagaon & 114365 & 23095 & 137460 \\
\cline { 1 - 4 } $\mathbf{3}$ & & Narayanpur & 22956 & 7537 & 30493 \\
\hline $\mathbf{4}$ & & Dantewada & 60582 & 4568 & 65150 \\
\hline $\mathbf{5}$ & & Sukma & 60612 & 8142 & 68754 \\
\hline $\mathbf{6}$ & & Bijapur & 52853 & 5225 & 58081 \\
\hline Total & & & & & 518970 \\
\hline
\end{tabular}


Table.2 Draught animal power in of Bastar plateau

\begin{tabular}{|c|c|c|c|}
\hline $\begin{array}{c}\text { Agro- climatic } \\
\text { zone }\end{array}$ & Name of District & $\begin{array}{c}\text { Availability of } \\
\text { draught } \\
\text { animal power, } \\
\text { kW/ha }\end{array}$ & $\begin{array}{c}\text { Average } \\
\text { draught } \\
\text { animal power, } \\
\mathbf{k W / h a}\end{array}$ \\
\hline \multirow{2}{*}{ Bastar Plateau } & Jagdalpur & 0.212 & \\
\cline { 2 - 4 } & Kondagaon & 0.28 & \\
\cline { 2 - 4 } & Dantewada & 0.15 & \multirow{2}{*}{0.208} \\
\hline & Sukma & 0.163 & \\
\hline & Narayanpur & 0.24 & \\
\hline
\end{tabular}

Table.3 Availability of farm implements and bullock carts in Bastar plateau

\begin{tabular}{|c|l|c|c|c|}
\hline S.No. & District & $\begin{array}{c}\text { Wooden } \\
\text { Plough }\end{array}$ & $\begin{array}{c}\text { Iron } \\
\text { Plough }\end{array}$ & Bullock Cart \\
\hline $\mathbf{1}$ & Bastar & 89110 & 1685 & 10355 \\
\hline $\mathbf{2}$ & Kondagaon & 81237 & 696 & 7810 \\
\hline $\mathbf{3}$ & Narayanpur & 18031 & 21 & 907 \\
\hline $\mathbf{4}$ & Kanker & 92666 & 747 & 12051 \\
\hline $\mathbf{5}$ & Dantewada & 50984 & 59 & 57 \\
\hline $\mathbf{6}$ & Sukma & 49071 & 741 & 762 \\
\hline $\mathbf{7}$ & Bijapur & 32551 & 46 & 2969 \\
\hline
\end{tabular}

Table.4 Average utilization of animal power in selected villages of Chhattisgarh

\begin{tabular}{|c|c|c|c|c|c|c|c|c|c|c|}
\hline \multirow[b]{2}{*}{$\begin{array}{l}\text { District/ } \\
\text { Block }\end{array}$} & \multirow[t]{2}{*}{ Village } & \multirow{2}{*}{$\begin{array}{c}\text { Area } \\
\text { (ha) }\end{array}$} & \multirow{2}{*}{$\begin{array}{c}\text { No. of } \\
\text { Draught } \\
\text { Pair }\end{array}$} & \multicolumn{4}{|c|}{ Implement wise Utilization (hrs) } & \multirow{2}{*}{$\begin{array}{c}\text { Total } \\
\text { Utilization }\end{array}$} & \multirow{2}{*}{$\begin{array}{l}\text { Utilization } \\
\text { Pair (hrs) }\end{array}$} & \multirow{2}{*}{$\begin{array}{l}\text { Use } \\
\text { h/ha }\end{array}$} \\
\hline & & & & Plough & $\begin{array}{c}\text { Wooden } \\
\text { Plank/ } \\
\text { Kopar }\end{array}$ & Threshing & Carting & & & \\
\hline \multicolumn{11}{|c|}{ Bastar Plateau (Agro- climatic Zone) } \\
\hline \multicolumn{11}{|c|}{ Kondagaon District } \\
\hline \multirow[t]{3}{*}{ Keskal } & Makadi & 20 & 14 & 1830 & 980 & 1084 & 1171 & 5065 & 361 & 253 \\
\hline & Anantpur & 17.16 & 11 & 1575 & 870 & 978 & 1024 & 4447 & 404 & 259 \\
\hline & Kerwahi & 18.33 & 14 & 1720 & 850 & 1021 & 987 & 4578 & 327 & 249 \\
\hline \multirow[t]{3}{*}{ Kondagaon } & Masora & 16.04 & 10 & 1510 & 820 & 876 & 920 & 4126 & 412 & 257 \\
\hline & Palli & 23.2 & 12 & 2190 & 1140 & 1234 & 1026 & 5590 & 465 & 240 \\
\hline & Badekanera & 11.45 & 10 & 1040 & 570 & 873 & 628 & 3111 & 311 & 271 \\
\hline \multicolumn{11}{|c|}{ Bastar District } \\
\hline \multirow[t]{3}{*}{ Bastar } & Baghmohalai & 22.29 & 11 & 2110 & 1070 & 1050 & 80 & 4310 & 391 & 193 \\
\hline & Bakel & 15 & 12 & 1610 & 770 & 870 & 120 & 3370 & 280 & 224 \\
\hline & Mathota & 11.125 & 10 & 950 & 520 & 750 & 0 & 2220 & 222 & 199 \\
\hline \multirow[t]{3}{*}{ Bakavand } & Kolawali & 17.08 & 13 & 1520 & 820 & 1030 & 72 & 3442 & 264 & 201 \\
\hline & Satosa & 16.83 & 10 & 1580 & 800 & 990 & 160 & 3530 & 353 & 209 \\
\hline & Chhindgaon & 7.5 & 10 & 670 & 550 & 630 & 0 & 1850 & 185 & 246 \\
\hline
\end{tabular}


Table.5 Month wise utilization of draught animals

\begin{tabular}{|c|c|c|}
\hline S.No & Month & Bastar Plateau \\
\hline $\mathbf{1}$ & May & 37 \\
\hline $\mathbf{2}$ & June & 9444 \\
\hline $\mathbf{3}$ & July & 7125 \\
\hline $\mathbf{4}$ & August & 0 \\
\hline $\mathbf{5}$ & Sept. & 0 \\
\hline $\mathbf{6}$ & Oct. & 19 \\
\hline $\mathbf{7}$ & Nov. & 6347 \\
\hline $\mathbf{8}$ & Dec. & 4988 \\
\hline $\mathbf{9}$ & Jan. & 0 \\
\hline $\mathbf{1 0}$ & Feb. & 0 \\
\hline $\mathbf{1 1}$ & March & 0 \\
\hline $\mathbf{1 2}$ & April & 0 \\
\hline
\end{tabular}

Table.6 Farm implements available in the selected villages

\begin{tabular}{|c|c|c|}
\hline S.No & Farm implements & Bastar plateau \\
\hline $\mathbf{1}$ & Tractor & 3 \\
\hline $\mathbf{2}$ & Desi plough & 126 \\
\hline $\mathbf{3}$ & M.B. plough & 1 \\
\hline $\mathbf{4}$ & Biasi plough & 97 \\
\hline $\mathbf{5}$ & Disc harrow & 0 \\
\hline $\mathbf{6}$ & Cultivator & 2 \\
\hline $\mathbf{7}$ & Wooden plank & 58 \\
\hline $\mathbf{8}$ & Koper & 54 \\
\hline $\mathbf{9}$ & Seed drill & 1 \\
\hline $\mathbf{1 0}$ & Rice transplanter & 0 \\
\hline $\mathbf{1 1}$ & Weeder & 0 \\
\hline $\mathbf{1 2}$ & Reaper/harvester & 0 \\
\hline $\mathbf{1 3}$ & Thresher & 1 \\
\hline $\mathbf{1 4}$ & Cage wheel & 4 \\
\hline $\mathbf{1 5}$ & others & 0 \\
\hline & & \\
\hline
\end{tabular}

Availability of farm implements in the selected villages

The farm implements were found in the selected villages which has shown in Table No. 6, in which 3 tractors found, desi plough 126, 1 mould board plough found in the selected villages, 97 biasi plough, no disc harrow found in the villages, 58 wooden planks, 54 kopar were found, 1 seed drill, 4 cage wheel. It showed that the selected villages depended on draught animal for farm operations. Bastar plateau contribute the largest area in the Chhattisgarh state. Two blocks namely Dongargarh and Chhuriya from Rajnandgaon district and Mahasamund and Pithora block were selected from Mahasamund district from Bastar plateau. Three villages from each block were selected for conduction of survey work. In this study, 
10 farmers from each of the village were interviewed personally for recording all necessary observation as per Proforma. It was observed that June and July months shows a rise in draught power utilization due to the time of tillage and intercultural operation for paddy crop, bullocks power utilization was confined for transportation in November.

The utilization in the month of December is mainly for threshing operation just after the harvest of paddy. The Bullocks are mostly unutilized in the month of February March and April due to mono-crop nature of the area.

The month wise bullock power utilization for a different category, it was observed that June and July are the peak period.

The highest utilization of bullocks power use/ha was noted in village Maharajpur of Bastar plateau and it was $316 \mathrm{~h} / \mathrm{ha}$.

Average farm power availability in the selected villages was found as 0.172 $\mathrm{kW} / \mathrm{ha}$ as compared to the average i.e. $1.098 \mathrm{~kW} / \mathrm{ha}$.

Based on the opinion of the respondents, rice transplanting and harvesting operations and winnowing/threshing involved a heavy level of drudgery followed by a medium to medium-heavy level of drudgeries in FYM application, preparatory work during seed-bed, intercultural operations. The rest of the operations involved a light and medium level of drudgery.

Most of the respondents used traditional farm tools/equipment for various farm operations.

\section{References}

Anonymous, 1987, "Utilization and Economics of Draught Animal Power", Proceedings of the National Seminar on Status of Animal Energy Utilization, ICAR-Central Institute of Agricultural
Engineering, Bhopal.

Dave, A. K. Thakare, S. K., and Sahare, P.U., 2000, Report on Status and Strategies of Farm Mechanization in Rajasthan, Department of Farm Machinery and Power Engineering, Maharana Pratap University of Agriculture and Technology, Udaipur-313001.

Haque, M.A., Umar, B. and Kawuyo, U.A., 2000. A preliminary survey on the use of animal power in agricultural operations in Adamawa state, Nigeria. Outlook on Agriculture, 29(2): 123-127

James Shaji, P. and Mohammad, C.P., 1988. Future of farm mechanization in Kerala. Technical paper (unpb.) Kelappaji College of Agricultural Engineering and Technology, Tavanur.

Mrema, G.C. and Mrema, M.J., 1993. Draft animal technology and agricultural mechanization in Africa, its potential role, and constraints. NAMANewsletter, (2): 12-13.

Ray, A.K., 1993. The present status of Agricultural mechanization and its constraints. Agric. Situ. India, 148(4) : 245-250.

Saxena, R., 1995. Status and utilization of draught animal power in Gujrat. Working paper Institute of Rural management Anand, (93): 14.

Shyam, M., Srivastava, N.S.L., and Ojha, T.P., 1987. Comparative energistics of animate and inanimate power source for potato cultivation. Technical bulletin No. CIAE/87/51, CIAE, Bhopal : 253259.

Singh, G. 2002. Spatial distribution and use of draught animal power in India. Indian Journal of Animal Sciences, 72:689-694.

Singh, Surendra, Singh, R.S and Singh S.P., 2010. Farm power availability and agricultural production scenario in India. Agricultural Engineering Today, 34(1): 9-20. 
How to cite this article:

Amit Namdeo, V. M. Victor and Navneet Kumar Dhruwe. 2020. Status of Farm Mechanization under Animal Farming in Bastar Plateau Agro-climatic Zone of Chhattisgarh. Int.J.Curr.Microbiol.App.Sci. 9(05): 427-433. doi: https://doi.org/10.20546/ijcmas.2020.905.047 